\section{Directed Evolution toward an Iron-Heme Enzyme for Asymmetric C-H Amination}

\section{Key words}

cytochrome P411

C-H amination directed evolution iron-heme enzyme

benzylamines

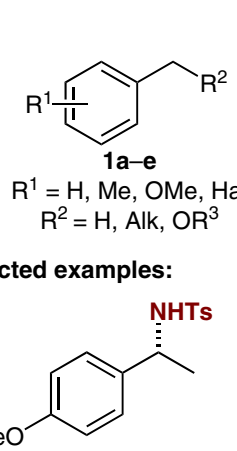
$2 \mathrm{a}$

$78 \%$ isolated yield 610 TON er $>$ 99.5:0.5 (0.25 mmol scale)<smiles>C[C@H](NC(C)(F)F)c1ccccc1</smiles>

2b

$15 \%$ yield

120 TON

er $>99.5: 0.5$

Directed evolution for $\mathbf{C}-\mathbf{H}$ amination:

\begin{tabular}{|c|c|c|c|}
\hline \multirow{3}{*}{$\begin{array}{c}1 \mathrm{a}+\mathrm{TsN}_{3} \\
(2 \text { equiv }) \\
\text { variant }\end{array}$} & \multicolumn{2}{|c|}{$\stackrel{\text { P411 variants }}{\longrightarrow} 2 a$} & \multirow[b]{3}{*}{ TON } \\
\hline & \multicolumn{2}{|c|}{ whole cells } & \\
\hline & yield & er & \\
\hline$P-4$ & $11 \pm 1 \%$ & $43: 57$ & 310 \\
\hline P-4 A82L & $51 \pm 3 \%$ & $88.5: 11.5$ & 1000 \\
\hline P-4 A82L A78V & $66 \pm 2 \%$ & $90: 10$ & 1200 \\
\hline $\begin{array}{c}\text { P-4 A82L A78V } \\
\text { F263L }\end{array}$ & $66 \pm 2 \%$ & $>99.5: 0.5$ & $N A$ \\
\hline $\begin{array}{c}\text { P-4 A82L A78V } \\
\text { F263L E267D } \\
\text { (P411 }{ }_{\text {CHA })}\end{array}$ & $66 \pm 3 \%$ & $>99.5: 0.5$ & 1000 \\
\hline
\end{tabular}

Significance: Arnold and co-workers report the directed evolution from iron-heme $\mathrm{P}^{4} 5 \mathrm{~B}_{\mathrm{BM} 3}$ to $\mathrm{P} 411_{\mathrm{CHA}}$ for the highly enantioselective intermolecular amination of benzylic $\mathrm{C}-\mathrm{H}$ bonds with up to 1300 catalytic turnovers. The authors suggest that the reaction proceeds through a commonly accepted iron nitrenoid intermediate, which undergoes nitrene insertion to afford valuable benzyl amines in up to $87 \%$ yield and >99.5:0.5 er.

SYNFACTS Contributors: Benjamin List, Jennifer L. Kennemur Synfacts 2017, 13(09), $0981 \quad$ Published online: 18.08.2017 Dol: 10.1055/s-0036-1590761; Reg-No.: B06417SF
Comment: The authors discovered that P-4, a $\mathrm{P}_{450} \mathrm{BM}_{3}$ variant with 17 mutations from the wildtype, catalyzes the benzylic $\mathrm{C}-\mathrm{H}$ amination of 4-ethylanisole, albeit with low enantioselectivity. Through sequential rounds of site-selective mutagenesis, $\mathrm{P}-411_{\mathrm{CHA}}$ was found to dramatically improve the yield and enantioselectivity of the reaction for a wide range of electronically-differentiated substrates. X-ray crystallography showed that all of the beneficial mutations lie within the active site of the enzyme. 